\title{
Chagas' disease: The Brazilian experience
}

$\mathrm{T}$ There is a growing interest on Chagas' disease in the most advanced research centers. This growing interest can be ascribed to some factors:

- The high prevalence of the disease that runs as high as $23 \%$ in blood donors in some countries such as Bolivia.

- The high populational migration rate from rural to urban areas. This phenomenon contributes to the dissemination of the disease.

- The morbidity and mortality rates caused by the disease's cardiac, digestive, and nervous system complications.

These facts mentioned before account for the great efforts that the distinct health programs are making in the countries where the Chagas' disease is very prevalent. These countries are: Bolivia, Mexico, Paraguay, Argentina, Venezuela, Chile, Panama, and other countries.

Several authors from countries as Japan, USA, England and France have, in association with other authors from high prevalence countries or not, published in the last few years epidemiological, clinical, immunology reports about Chaga's disease. Additionally, other reports about the treatment of Chagas' infection and its complications in the different systems and organs clearly demonstrates the interest this medical condition produces in the research community.

The Brazilian experience relates to a fundamental problem: the Public Health as a regional, nationwide and worlwide problem. In the search for a solution, it is understood that some reports in the medical literature indicate that Chagas' disease is the factor responsible for $0.9 \%$ of all deaths in the state of São Paulo alone, with a higher prevalence in the male gender. On the other hand, other reports document the morbidity of the Chagas' Disease in USA immigrants and the disease's transmission risks in the US.

At this present time, when boundaries, borders and barriers are either flexible or absent, it is necessary to contemplate the causes of the disease and contemplate the means to protect the population.

In the year of 1994, the discussion entitled Elimination of Transmission of Chagas' Disease in the Southernmost Latin America was held at the World Health Forum. This accounts for our earnest concern and reinforces the real demand for a worldwide public health assistance strategic policy.

The Brazilian scientific community is searching for alternatives and more efficient responses for these questions. This publication is a righteous instance of this effort. Reports and research outcomes are presented in this issue of the São Paulo Medical Journal. This was aimed at informing, analyzing and discussing the State of the Art on Chagas' heart disease. This essay may even become a valuable instrument for the northern hemisphere countries that are struggling against the dissemination of 
the Chagas' disease as well struggling with efforts to prevent its associated morbidity and mortality.

\section{REFERENCES}

APPELMAN, M.D.; SHULMAN, I.A.; SAXENA, S. \& KIRCHHOFF, L.V. - Use of a questionnaire to identify potential blood donors at risk for infection with Trypanosoma cruzi. Transfusion, 33 (1):61-4, 1993.

DIAS, J.C. - The clinical, social and occupational aspects of Chagas'disease in an endemic area under the control of the state of Minas Gerais, Brazil. Rev.Soc.Bras.Med.Trop., 26(2):93-9, 1993.

Elimination of transmission of Chagas' disease in southernmost Latin America (news). World Health Forum, 15(3):299300, 1994.

ESQUIVEL, M.L. \& SEGURA, E.L. - Calculating the number of patients with Chagas'disease in Argentina (letter). Medicina (B. Aires), 54(1):91-2, 1994.

KIRCHHOFF, L.V. - Chagas' disease. American trypanosomiasis. Infect Dis Clin North Am 7(3):487-502,1993.

KIRCHHOFF, L.V. - American trypanosomiasis (Chagas' disease) a tropical disease now in the United States. N England J Med 329 (9):639-44, 1993.
LITVOC, J.; WANDERLEY, D.M. \& CAMARGO, L.M. Mortality due to Chagas' disease in São Paulo State (Brazil): subsidy for the planning of Chagasic patient care. Rev Saúde Pública 26 (2):59-62, 1992.

MILEI, J.; MAUTNER, B.; STORINO, R.; SANCHEZ, J.A. \& FERRANS, V.J. - Does Chagas' disease exist as an undiagnosed form of cardiomyopathy in the United States? (editorial) Am Heart J 123 (6): 1732-5, 1992.

MIYOSHI, C.; TANABE, M.; KAWAI, S.; HONDA, S.; SAKUMA, F.; KATAYAMA, T.; ROJAS, E. \& ROSADO, D. - Chagas' disease among blood donors in Bolivia. Nippon Koshu Eisei Zasshi 41 (10):1027-31, 1994.

PRATA, A. - Chagas' disease. Infect Dis Clin North Am 8(1):6176, 1994.

REYS, P.A. - Chagas' disease in the United States (letter; comment). Am Heart J 123 (6): 1724, 1992.

RUEGSEGGER DE GUTIERREZ, G.L.; MONTEON, V.M.; MARCUSCHAMER, J. \& REYES, P.A. - American trypanosomiasis (Chagas' disease). A clinico-serological surgery in a rural community of Oaxaca. Arch Inst Cardiol Mex 63 (2):145-8, 1993.

SALGADO, W.; NOBRE, F.; BRASIL, J.C. \& VICHI, F.L. Heart rate in chronic Chagas' cardiopathy. 1. Distribution of heart rate in patients with chronic Chaga's cardiopathy. Arq Bras Cardiol 30 (1):43-6, 1997.

WALSH, J.F.; MOLINEU, D.H.; BIRLEY, M.H. - Deforestation: effects on vector-borne disease. Parasitology 106 (suppl. P):555-75, 1993. 